[J. Appl. Glycosci., Vol. 48, No. 1, p. 45-54 (2001)]

\title{
Purification and Properties of Three Endo-xylanases from Acremonium cellulolyticus
}

\author{
Takanori Nihira, ${ }^{1}$ Supannee Kansarn, ${ }^{1}$ Toshiaki Kono ${ }^{2}$ and Gentaro Okada ${ }^{1,3, *}$ \\ ${ }^{1}$ The Graduate School of Electronic Science and Technology, Shizuoka University \\ (3-5-1, Johoku, Hamamatsu 432-8561, Japan) \\ ${ }^{2}$ Bio Science Laboratories, Meiji Seika Kaisha, Ltd. (5-3-1, Chiyoda, Sakado 350-0289, Japan) \\ ${ }^{3}$ Department of Biology, Faculty of Education, Shizuoka University (836, Ohya, Shizuoka 422-8529, Japan)
}

\begin{abstract}
Three distinct endo-xylanase components derived from Acremonium cellulase, a commercial cellulase product from a filamentous fungus Acremonium cellulolyticus, were extensively purified by consecutive column chromatographies and designated as xylanase I, xylanase II and xylanase III. Xylanases I, II and III were each homogeneous on both Native- and SDS-PAGE. The molecular weight (SDS-PAGE) and $\mathrm{p} I$ values of xylanases I, II and III were $30 \mathrm{kDa}$ and $5.1,25.5 \mathrm{kDa}$ and 5.2 , and $33.5 \mathrm{kDa}$ and 5.7 , respectively. The $\mathrm{N}$-terminal amino acid sequences from the $1 \mathrm{st}$ up to the 25th residue of three enzymes were identical as follows: $\mathrm{NH}_{2}$-Ala-Glu-Ala-Ile-Asn-Tyr-Asn-GlnAsn-Tyr-Ile-Ala-Ser-Gly-Ala-Asn-Val-Gln-Tyr-Ser-Pro-Asn-Ile-Ala-Ala-. Xylanases I, II and III had high, specific soluble xylan saccharification activities of $112.1,86.1$ and $74.8 \mathrm{U} / \mathrm{mg}$ of protein, respectively. The optimum $\mathrm{pH}$ and temperature for xylanases I, II and III were $\mathrm{pH} 3.5$ and $55^{\circ} \mathrm{C}$, $\mathrm{pH} 3.8$ and $55^{\circ} \mathrm{C}$, and $\mathrm{pH} 3.5$ and $50^{\circ} \mathrm{C}$, respectively. Xylanases I, II and III were completely stable over the ranges of $\mathrm{pH} 3.5-9.5$ at $25^{\circ} \mathrm{C}$ for $2 \mathrm{~h}$ and at temperatures below $55^{\circ} \mathrm{C}, \mathrm{pH} 3.0^{-}-9.5$ and below $55^{\circ} \mathrm{C}$, and $\mathrm{pH} 2.5-9.5$ and below $50^{\circ} \mathrm{C}$, respectively. The enzymes were almost completely inhibited by $1 \mathrm{mM} \mathrm{KMnO}$ and partially by $1 \mathrm{mM}$ SDS, PCMB, $\mathrm{Zn}^{2+}$ and $\mathrm{Ag}^{+}$. Substrate specificities and kinetic parameters for these enzymes were precisely examined. The enzymes were characterized as endo-type xylanases on the basis of their action patterns on soluble xylan and xylooligosaccharides. Xylanases I, II and III seem to be isoforms judging from $\mathrm{N}$-terminal amino acid sequences and basic physicochemical and enzymatic properties as well as substrate specificities.
\end{abstract}

$\beta-1,4-X y l a n s$, the major components of hemicellulose in plant cell walls are heterogeneous polysaccharides, the most abundant resources in nature next to cellulose. These polysaccharides

\footnotetext{
${ }^{*}$ Corresponding author.

Abbreviations: QAE, quaternary aminoethyl; DEAE, diethylaminoethyl; PAGE, polyacrylamide gel electrophoresis; SDS, sodium dodecyl sulfate; DP, degree of polymerization; $\overline{\mathrm{DS}}$, average degree of substitution; NBS, $N$-bromosuccinimide; $\beta$-PNPX, $p$-nitrophenyl $\beta$ D-xyloside; $\beta$-PNPG, $p$-nitrophenyl $\beta$-D-glucoside; $\alpha$ PNPA, $p$-nitrophenyl $\alpha$-L-arabinoside ; $\beta$-PNPC, $p$ nitrophenyl $\beta$-D-cellobioside; $\mathrm{X}_{1}$, D-xylose; $\mathrm{X}_{2}-\mathrm{X}_{6}$, xylooligosaccharides from xylobiose to xylohexaose; PCMB, $p$-chloromercuribenzoic acid; CBB, Coomassie Brilliant Blue; FPLC, fast protein liquid chromatography; HPLC, high-pressure liquid chromatography.
}

have a backbone of $\beta$-1,4-linked xylose and side chains of $\alpha-1,3$-linked arabinose and glucuronic acid. 1,4- $\beta$-D-Xylanases (EC 3.2.1.8, 1,4- $\beta$-Dxylan xylanohydrolase) of endo-type are the only xylanases that have been unequivocally characterized. ${ }^{1)}$ The xylanases of this type hydrolyze the 1,4$\beta$-D-xylopyranosyl linkages of D-xylans such as Larabino-D-xylan, L-arabino-D-glucurono-D-xylan, Larabino-4- $O$-methyl-D-glucurono-D-xylan and Dglucurono-D-xylan.

Endo-xylanases have been widely distributed in bacteria, fungi, yeasts and streptomycetes, and their characteristic properties have been reported. ${ }^{2,3)}$ The enzymes are particularly important in biotechnological applications, especially in the paper industry. In our recent work, ${ }^{4,5)}$ we reported the puri- 
fication and characterization of three major cellulase components from the commercial cellulase product of Acremonium cellulolyticus. During the purification processes of these cellulase components, we noticed that at least three xylanase components exist in this commercial cellulase preparation of A. cellulolyticus. Little is yet known about the xylan degrading enzymes from Acremonium sp.

This paper describes the purification, physicochemical and enzymatic properties of three mesophilic endo-xylanases from A. cellulolyticus.

\section{MATERIALS AND METHODS}

Crude enzyme material. The spray-dried cellulase product from the liquid culture filtrate of Acremonium cellulolyticus (Acremonium cellulase, lot No. AUS-0301) was kindly supplied by Meiji Seika Kaisha, Ltd., Japan, and used as a starting material for the purification of xylanases.

Materials. Xylans from oat spelts, birchwood and larchwood, $\beta$-PNPX and $\alpha$-PNPA, were products of Sigma Chemical Co., USA. Xylooligosaccharides $\left(\mathrm{X}_{2}-\mathrm{X}_{6}\right)$ were prepared from insoluble xylan. Sodium carboxymethylcellulose (CMC), cellogen WS-C $(\overline{\mathrm{DS}}=0.62-0.68)$, was kindly supplied from Daiichi Industrial Pharmaceutical Co., Ltd., Japan. A microcrystalline cellulose powder (Avicel) was obtained from Asahi Kasei Co., Ltd., Japan, and $\beta$-PNPG was a product of Tokyo Kasei Kogyo Co., Ltd., Japan. $\beta$-PNPC was synthesized by the method of Nisizawa and Wakabayashi. ${ }^{6}$ QAE-Toyopearl 550C and DEAE-Toyopearl 650S were the products of Tosoh, Japan, and Mono S and Superdex 75 were from Amersham Pharmacia Biotech, Sweden. SDS-PAGE molecular weight standards (low range of 14.4 to $97.4 \mathrm{kDa}$ ) were products of Bio-Rad Laboratories, USA. The Ampholine PAGPlate ( $\mathrm{pH} 3.5-9.5,245 \times 110 \times 1 \mathrm{~mm})$ and IEF Calibration Broad $\mathrm{pI}$ Kit ( $\mathrm{pH} 3-10)$ were products of Amersham Pharmacia Biotech, Sweden. All other reagents were of analytical grade.

Preparation of soluble xylan. A $2 \%(\mathrm{w} / \mathrm{v})$ suspension of xylan (oat spelts) was heated in a boiling water bath for $2 \mathrm{~h}$. After this heat treatment, the xylan solution was centrifuged at 10,000 $\times g$ for $20 \mathrm{~min}$ at $4^{\circ} \mathrm{C}$ to remove insoluble materials. The resulting supernatant was lyophilized, and used as a soluble xylan for the following enzyme assay.

\section{Enzyme assays.}

(a) Soluble xylan saccharification activity.

Soluble xylan saccharification activity was used as the standard assay. The reaction mixture contained $0.25 \mathrm{~mL}$ of $1 \%$ soluble xylan solution, $0.5 \mathrm{~mL}$ of $50 \mathrm{mM}$ acetate buffer ( $\mathrm{pH} \mathrm{3.5)}$, and $0.25 \mathrm{~mL}$ of the enzyme solution. The mixture was incubated at 30 ${ }^{\circ} \mathrm{C}$ for an appropriate period. Reducing sugars formed per $1.0 \mathrm{~mL}$ of the mixture were determined by the colorimetric method of Somogyi ${ }^{7}$-Nelson. ${ }^{8}$ One unit (U) was defined as the amount of enzyme that released reducing sugars equivalent to $1.0 \mu \mathrm{mol}$ of $\mathrm{D}$-xylose from the substrate per minute under the assay conditions.

(b) Insoluble xylan saccharification activity. The reaction mixture was composed of $40 \mathrm{mg}$ xylan powder and $2.0 \mathrm{~mL}$ of enzyme solution in 20 $\mathrm{mM}$ acetate buffer ( $\mathrm{pH} 3.5$ ). Incubation was carried out at $30^{\circ} \mathrm{C}$ for an appropriate period. The reaction was stopped by the addition of $20 \mu \mathrm{L}$ of $2 \mathrm{M}$ $\mathrm{NaOH}$ solution. After centrifugation of the mixture at $2000 \times g$ for $20 \mathrm{~min}, 1.0 \mathrm{~mL}$ of the supernatant was carefully withdrawn and analyzed for reducing sugar by the colorimetric method of Somogyi ${ }^{7}$ Nelson. ${ }^{8)}$

(c) Aryl-glycosidase activity. The reaction mixture, containing $0.05 \mathrm{~mL}$ of $13.6 \mathrm{mM}$ each arylglycoside, $0.10 \mathrm{~mL}$ of $50 \mathrm{mM}$ acetate buffer $(\mathrm{pH}$ 3.5 ) and $0.05 \mathrm{~mL}$ of enzyme solution; was incubated at $30^{\circ} \mathrm{C}$ for an appropriate period. The reaction was stopped by the addition of $5 \mathrm{~mL}$ of $0.1 \mathrm{M}$ $\mathrm{Na}_{2} \mathrm{CO}_{3}$ to the mixture $(0.2 \mathrm{~mL})$, and then the amount of $p$-nitrophenol liberated was colorimetrically measured by absorbance at $420 \mathrm{~nm}$. One unit (U) of the enzyme activity was defined as the amount of enzyme that produces $1.0 \mu \mathrm{mol}$ of $p$ nitrophenol under the assay conditions.

Protein assays. Protein content was measured by the method of Lowry et al. ${ }^{9)}$ with crystalline bovine serum albumin as the standard. The absorbance at $280 \mathrm{~nm}$ was used for monitoring protein in column effluents.

Electrophoresis. Polyacrylamide gel electro- 
phoresis (Native-PAGE) was done in $12.5 \%$ polyacrylamide with Tris-glycine buffer $(\mathrm{pH}$ 6.8) by the method of Ornstein ${ }^{10)}$ and Davis. ${ }^{11)}$ SDS-PAGE was done in $12.5 \%$ polyacrylamide containing $0.1 \%$ SDS by the method of Laemmli. ${ }^{12)}$ In both cases, the gels were stained with CBB R-250 or a silver staining kit (Silver Stain II Kit, Wako). The isoelectric points of the purified enzymes were estimated by the method of Vesterberg ${ }^{13)}$ using Ampholine PAGPlate (pH 3.5-9.5) and a LKB Multiphor II Electrophoresis Unit (Model 2117). Standard proteins with $\mathrm{p} I$ values ranging from 3 to 10 (Amersham Pharmacia Biotech) were run simultaneously. Gels were stained with $0.25 \%$ CBB R-250 for $10 \mathrm{~min}$ and destained with $8.0 \%(\mathrm{v} / \mathrm{v})$ acetic acid until the background became clear.

Analysis of N-terminal amino acid sequence. The N-terminal amino acid sequences of the purified enzymes were analyzed by $\mathrm{N}$-terminal Edman degradation employing a protein sequencer, $\mathrm{PE}$ Model 492 (Perkin-Elmer Co., USA).

Viscometry. The changes in viscosity during the enzymatic hydrolysis of soluble xylan were measured at intervals with a Canon-Fenske viscometer $(c=0.0369)$. The enzyme activity was expressed in terms of specific fluidity, $\phi_{\text {sp. }}$ (i.e., $1 / \eta_{\text {sp. }}$ ).

High-pressure liquid chromatography (HPLC). Xylooligosaccharides were separated and identified by HPLC on a Shimadzu LC-6 system with a LC6AD pump (Shimadzu Corporation), RID-6A refractive index detector (Shimadzu Corporation) and C-R4A integrator (Shimadzu Corporation) under the following conditions: column, "Aminex HPX-42A $(7.8 \times 300 \mathrm{~mm}$, Bio-Rad Laboratories); column temperature, $80^{\circ} \mathrm{C}$; mobile phase, deionized water; and flow rate, $0.7 \mathrm{~mL} / \mathrm{min}$.

Kinetic studies. The kinetic parameters of the purified enzymes were measured using soluble xylan and a series of xylooligosaccharides ( $D P=4-$ 6 ). The initial reaction velocities for soluble xylan and xylooligosaccharides were determined by the colorimetric method of Somogyi ${ }^{7)}-$ Nelson $^{8)}$ and by HPLC analysis, respectively. The $K_{\mathrm{m}}$ and $V_{\max }$ values were calculated from double reciprocal plots. $^{14)}$

\section{RESULTS}

\section{Purification of the enzymes.}

Unless otherwise stated, all purification procedures for the enzymes were carried out in a cold room $\left(4^{\circ} \mathrm{C}\right)$. The operations of FPLC were done at room temperature $\left(25^{\circ} \mathrm{C}\right)$. The enzyme solution collected in each purification step was concentrated and dialyzed by a Diaflo ultrafiltration apparatus with a PM 10 membrane (Amicon Corp, USA).

Commercial enzyme powder (5 g) was mixed with $50 \mathrm{~mL}$ of $20 \mathrm{mM}$ acetate buffer (pH 5.5) by carefully stirring overnight at $4{ }^{\circ} \mathrm{C}$. The crude enzyme extract was centrifuged at $2000 \times g$ for 20 min at $4{ }^{\circ} \mathrm{C}$. The resulting supernatant was used as a starting material for purification.

(1) QAE-Toyopearl 550C column chromatography. The starting enzyme material was put on a QAE-Toyopearl $550 \mathrm{C}$ column $(4.4 \times 47 \mathrm{~cm})$ preequilibrated with $20 \mathrm{mM}$ acetate buffer ( $\mathrm{pH} 5.5$ ). Elution was done stepwise with the same buffer containing 0,150 and $500 \mathrm{mM} \mathrm{NaCl}$ at a flow rate of $3 \mathrm{~mL} / \mathrm{min}$. Each $200 \mathrm{~mL}$ fraction was collected and assayed for xylanase activity. Four protein peaks (Peaks I-IV) were obtained (Fig. 1). Two peak fractions (Peaks I and III) showed xylanase activity toward soluble xylan (Fig. 1). Between them, the Peak I fraction had a potent xylanase activity compared to the Peak III fraction. Therefore, the Peak I fraction (fraction Nos. 3-6) was collected, concentrated to about $15 \mathrm{~mL}$ by ultrafiltration, and dialyzed overnight against $20 \mathrm{mM}$ acetate buffer (pH 6.0).

(2) DEAE-Toyopearl 650S column chromatography. The dialyzed sample was put on a DEAEToyopearl $650 \mathrm{~S}$ column $(2 \times 35 \mathrm{~cm})$ preequilibrated with $20 \mathrm{mM}$ acetate buffer ( $\mathrm{pH} 6.0$ ): Elution was done stepwise with $20 \mathrm{~mm}$ acetate buffer ( $\mathrm{pH}$ 5.5) containing $0,150 \mathrm{mM} \mathrm{NaCl}$ at'a flow rate of $0.3 \mathrm{~mL} / \mathrm{min}$. The elution profiles are shown in Fig. 2. The non-adsorbed active fractions (fraction Nos. 8-12). were pooled, concentrated, and dialyzed overnight against $100 . \mathrm{mm}$ acetate buffer ( $\mathrm{pH}$ 3.5).

(3) Mono $S$ column chromatography. The 


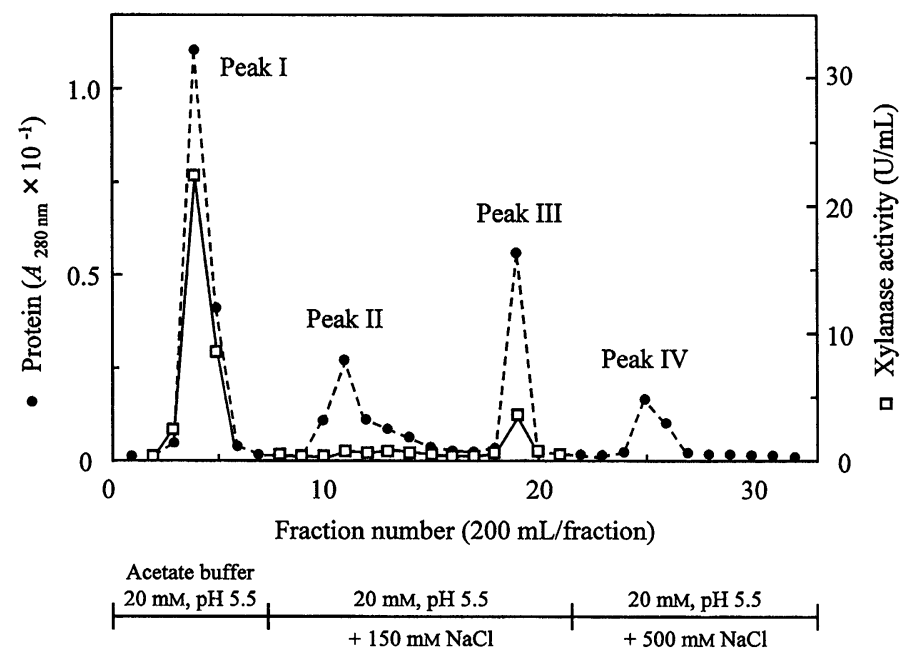

Fig. 1. Elution profiles of the crude enzyme material on QAEToyopearl 550C column chromatography.

๑, protein $\left(A_{280 \mathrm{~nm}} \times 10^{-1}\right) ; \square$, xylanase activity $(\mathrm{U} / \mathrm{mL})$

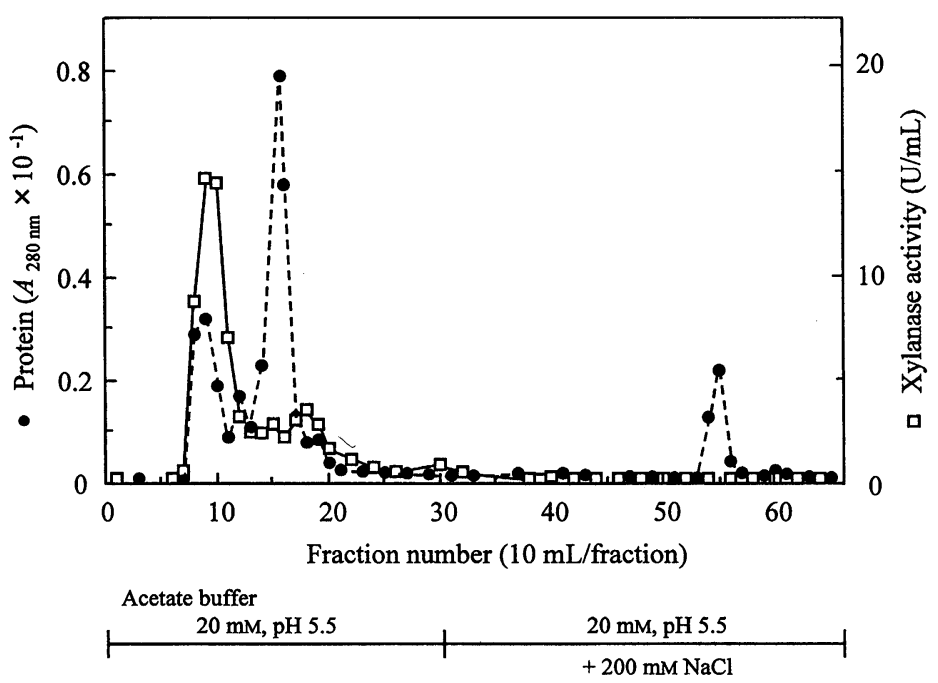

Fig. 2. Elution profiles of the Peak I fraction on DEAE-Toyopearl 650S column chromatography.

๑, protein $\left(A_{280 \mathrm{~nm}} \times 10^{-1}\right) ; \square$, xylanase activity $(\mathrm{U} / \mathrm{mL})$

dialyzed sample was further applied to a Mono $\mathrm{S}$ HR10/10 FPLC column $(1 \times 10 \mathrm{~cm})$ pre-equilibrated with $100 \mathrm{mM}$ acetate buffer ( $\mathrm{pH} 3.5)$ before the sample loading. The column was then eluted by a linear gradient of 0 to $45 \mathrm{mM} \mathrm{NaCl}$ in $100 \mathrm{mM}$ acetate buffer $(\mathrm{pH} 3.5)$ at a flow rate of $0.5 \mathrm{~mL} / \mathrm{min}$. Two protein fractions (F I and F II) were obtained and both fractions possessed potent xylanase activity. The eluates forming F I and F II were separately combined and concentrated.
(4) Gel filtration on Superdex 75. Each concentrate was dialyzed overnight against $50 \mathrm{~mm}$ acetate buffer (pH 3.5) containing $100 \mathrm{mM} \mathrm{NaCl}$. Each dialyzed sample was separately applied to a Superdex 75 HR10/30 FPLC column $(1 \times 30 \mathrm{~cm})$ pre-equilibrated with the same buffer, and the column was then eluted with the same buffer at a flow rate of $0.5 \mathrm{~mL} / \mathrm{min}$. A symmetrical protein peak from F I and two symmetrical protein peaks from F II containing only xylanase activity were 
obtained, respectively. The active fractions were separately combined as the purified enzymes. The purified enzymes were designated as xylanase I, xylanase II and xylanase III, and they gave a single protein band on both Native- and SDS-PAGE, respectively (Fig. 3).

Table 1 summarized the specific activity and yield of xylanases I, II and III during each purification step. Xylanases I, II and III had specific soluble xylan saccharification activities of 112.1, 86.1 and $74.8 \mathrm{U} / \mathrm{mg}$ of protein in the final yields of $22.0,11.0$ and $7.0 \%$, respectively, and were used in the subsequent characterization.

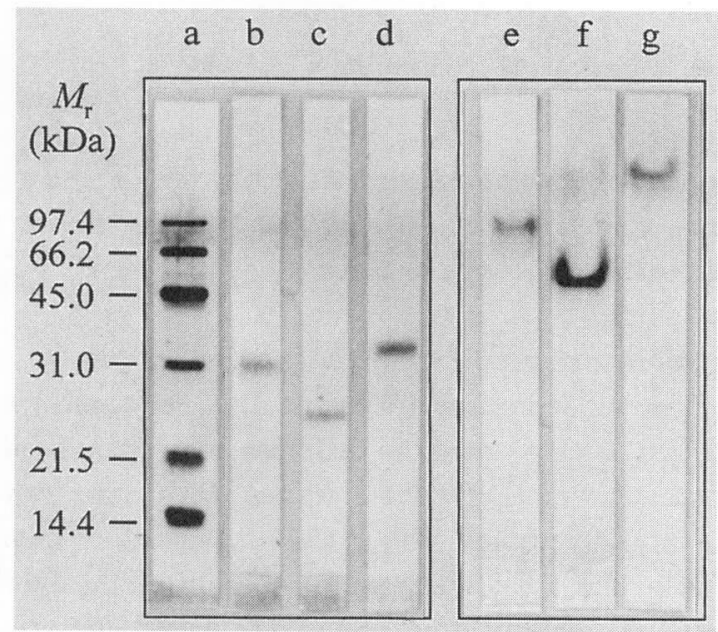

Fig. 3. Native- and SDS-PAGE of the purified enzymes.

Lane a, standard protein mixture containing phosphorylase $b(97.4 \mathrm{kDa})$, bovine serum albumin (66.2), ovalbumin (45.0), carbonic anhydrase (31.0), soybean trypsin inhibitor (21.5), and lysozyme (14.4); lanes b, c and d, xylanases I, II and III on SDS-PAGE, respectively; lanes e, $\mathrm{f}$ and g, xylanases I, II and III on Native-PAGE, respectively.

\section{Physicochemical properties of the purified en- zymes.}

The molecular weights of xylanases I, II and III were estimated to be about $30,25.5$ and $33.5 \mathrm{kDa}$, respectively, by comparison of their relative mobilities on SDS-PAGE with those of standard proteins (Fig. 3). The isoelectric points of xylanases I, II and III determined by isoelectric focusing were about 5.1, 5.2 and 5.7, respectively. The $\mathrm{N}$ terminal amino acid sequences from the 1 st up to the 25 th residue of xylanases I, II and III were all identical as follows: $\mathrm{NH}_{2}$-Ala-Glu-Ala-Ile-Asn-TyrAsn-Gln-Asn-Tyr-Ile-Ala-Ser-Gly-Ala-Asn-ValGln-Tyr-Ser-Pro-Asn-Ile-Ala-Ala-.

\section{Effects of $\mathrm{pH}$ and temperature on the activities of the purified enzymes.}

The effects of $\mathrm{pH}$ and temperature on the activities of the purified xylanases were studied under the standard assay conditions toward $0.25 \%$ soluble xylan at $30^{\circ} \mathrm{C}$ for $10 \mathrm{~min}$ using $25 \mathrm{mM}$ McIlvaine buffers at $\mathrm{pH} \quad 2.5-8.0$ and at different reaction temperatures for $10 \mathrm{~min}$. The optimum $\mathrm{pHs}$ and temperatures for xylanases I, II and III were 3.5 and $55^{\circ} \mathrm{C}, 3.8$ and $55^{\circ} \mathrm{C}, 3.5$ and $50^{\circ} \mathrm{C}$, respectively.

\section{Stabilities of the purified enzymes toward $\mathrm{pH}$ and temperature.}

Each solution containing an equal amount of the purified enzyme (each $0.15 \mathrm{U}$ ) was individually adjusted to a $\mathrm{pH}$ value from 2.0 to 12.0 by adding $45 \mu \mathrm{L}$ of $25 \mathrm{mM}$ McIlvaine or Britton-Robinson buffer. After the buffered enzyme solutions had been kept at $25^{\circ} \mathrm{C}$ for $2 \mathrm{~h}$, each $10 \mu \mathrm{L}$ of enzyme

Table 1. Recoveries and activities of three purified xylanases during purification.

\begin{tabular}{|c|c|c|c|c|c|c|}
\hline \multirow{2}{*}{\multicolumn{2}{|c|}{ Purification step }} & \multirow{2}{*}{$\begin{array}{c}\text { Total } \\
\text { protein } \\
(\mathrm{mg})\end{array}$} & \multicolumn{3}{|c|}{ Enzyme activity } & \multirow[b]{2}{*}{$\begin{array}{l}\text { Purification } \\
\text { (fold) }\end{array}$} \\
\hline & & & Total unit & Yield $(\%)$ & $\begin{array}{c}\text { Specific activity } \\
(\mathrm{U} / \mathrm{mg})\end{array}$ & \\
\hline \multicolumn{2}{|c|}{ 1. Crude enzyme extract } & 76.70 & 145.24 & 100.0 & 1.9 & 1 \\
\hline \multicolumn{2}{|l|}{ 2. QAE-Toyopearl } & 38.70 & 123.89 & 85.3 & 3.2 & 1.7 \\
\hline \multicolumn{2}{|l|}{ 3. DEAE-Toyopearl } & 12.82 & 98.91 & 68.2 & 7.7 & 4.1 \\
\hline \multirow{2}{*}{ 4. Mono S } & & 0.37 & 39.80 & 27.4 & 107.6 & 56.6 \\
\hline & & 0.35 & 28.76 & 19.8 & 82.2 & 43.3 \\
\hline 5. Superdex 75 (F I) & Xylanase I & 0.285 & 31.95 & 22.0 & 112.1 & 59.0 \\
\hline \multirow{2}{*}{ 6. Superdex 75 (F II) } & Xylanase II & 0.186 & 16.02 & 11.0 & 86.1 & 45.3 \\
\hline & Xylanase III & 0.136 & 10.17 & 7.0 & 74.8 & 39.4 \\
\hline
\end{tabular}


sample was then examined for remaining soluble xylan saccharification activity by the standard assay at $30^{\circ} \mathrm{C}$ for $10 \mathrm{~min}$. Xylanases I, II and III were stable over the ranges of $\mathrm{pH} 3.5-9.5, \mathrm{pH} 3.0^{-}$ 9.5 and $\mathrm{pH} 2.5-9.5$ at $25^{\circ} \mathrm{C}$, respectively.

Each purified enzyme (0.03 U, pH 3.5) was heated at various temperatures for $10 \mathrm{~min}$, and then cooled immediately in an ice-bath. The remaining soluble xylan saccharification activity was then measured by the standard assay at $30^{\circ} \mathrm{C}$ for $10 \mathrm{~min}$. Xylanases I, II and III were completely stable at temperatures below 55,55 and $50^{\circ} \mathrm{C}$, respectively.

\section{Effects of various metal ions and several en- zyme inhibitors on the activities of the purified enzymes.}

The enzyme was incubated with an equal volume of each metal ion or enzyme inhibitor solution $(2 \mathrm{mM}, \mathrm{pH} 3.5)$ at $30^{\circ} \mathrm{C}$ for $30 \mathrm{~min}$. Then the mixtures were diluted 50 -fold with $50 \mathrm{mM}$ acetate buffer ( $\mathrm{pH} 3.5$ ), and the remaining enzyme activity per milliliter of each reaction mixture containing $0.03 \mathrm{U}$ of enzyme was examined by the standard assay at $30^{\circ} \mathrm{C}$ for $10 \mathrm{~min}$. Inactivations of xylanases I, II and III were found to be extremely strong with $1 \mathrm{mM} \mathrm{KMnO}_{4}$ being about 98, 95 and $98 \%$ inhibition, and also partial with $1 \mathrm{~mm}$ SDS, PCMB, $\mathrm{Zn}^{2+}$ and $\mathrm{Ag}^{+}$being about 33, 52, 76; 23, 9, $46 ; 25,6,5 ; 16,0,19 \%$ inhibition, respectively. EDTA, NBS and other metal ions tested had no inhibitory effect on the activities of the enzymes.

\section{Mode of action of the purified enzymes toward soluble xylan.}

The mode of action of the enzymes toward soluble xylan was analyzed by viscometry. The reaction mixture was composed of $4 \mathrm{~mL}$ of $50 \mathrm{mM}$ acetate buffer ( $\mathrm{pH}$ 3.5) containing $0.5 \%$ soluble xylan and $4 \mathrm{~mL}$ of the enzyme solution $(0.005 \mathrm{U}$ each). The mixture was incubated in a CanonFenske viscometer at $30^{\circ} \mathrm{C}$. The decrease in viscosity of the incubation mixture and formation of reducing sugars were measured every $5 \mathrm{~min}$. Then the increases in specific fluidity $\left(\phi_{\mathrm{sp}}\right.$.) were plotted against the increases in reducing power. As can be seen in Fig. 4, straight lines with almost the same

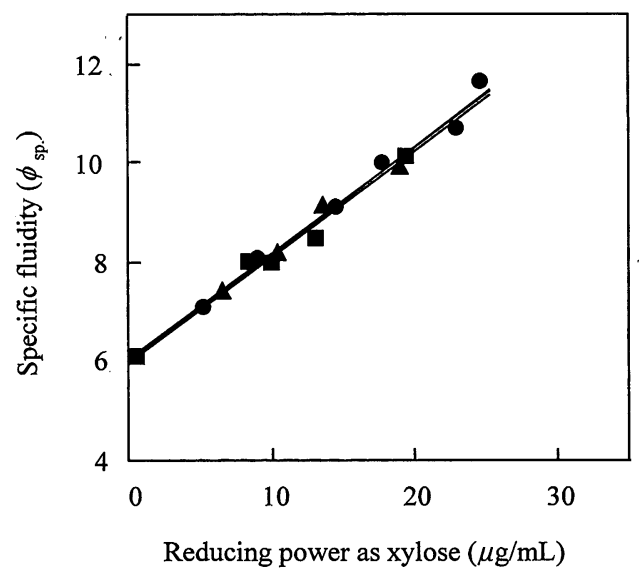

Fig. 4. Relationship between increases in specific fluidity and reducing power during the hydrolysis of soluble xylan by the purified enzymes.

○, xylanase I; $\mathbf{\square}$, xylanase II; $\boldsymbol{\Delta}$, xylanase III.

slopes were obtained for these enzymes. These results clearly indicate that the purified enzymes are all typical endo-type xylanases.

\section{Substrate specificity of the purified enzymes.}

The substrate specificity of the enzymes was studied using xylan from different sources, xylooligosaccharides (DP=2-6), Avicel, CMC and various aryl-glycosides. The reaction systems are identical in the assay systems for soluble or insoluble xylan saccharification activity, and also arylglycoside activity. Reducing sugar or $p$ nitrophenol formed in the reaction mixture was colorimetrically measured as described in Materials and Methods.

As can be seen in Table 2, it is clear that three purified xylanases show high levels of specific activity toward various xylans to different extents. The enzymes hydrolyzed xylans to give $X_{2}$ as the major end product without exception. The hydrolysis extents toward soluble xylan by xylanases I, II and III were about 15, 13.4 and 12\%, respectively, under the standard assay conditions at $24 \mathrm{~h}$ incubation (Fig. 5). On the other hand, these purified xylanases had absolutely no action on Avicel, CMC, xylotriose, xylobiose and various arylglycosides tested.

The hydrolysis products from xylooligosaccharides by the purified enzymes were analyzed by 
Table 2 . Substrate specificities of xylanases I, II and III.

\begin{tabular}{lccc}
\hline \multicolumn{1}{c}{ Substrate } & \multicolumn{3}{c}{ Specific activity (U/mg protein) } \\
\cline { 2 - 4 } & Xylanase I & Xylanase II & Xylanase III \\
\hline Soluble xylan & 112.1 & 86.1 & 74.8 \\
Insoluble xylans & & & \\
$\quad$ Oat spelts & 76.6 & 87.6 & 101.5 \\
$\quad$ Birch wood & 150.1 & 125.1 & 117.0 \\
Larch wood & 122.2 & 250.4 & 140.2 \\
Avicel & 0 & 0 & 0 \\
CMC & 0 & 0 & 0 \\
Xylooligosaccharides $\left(\mathrm{X}_{4}-\mathrm{X}_{6}\right)$ & & & \\
Xylobiose & 0 & 0 & 0 \\
Xylotriose & 0 & 0 & 0 \\
$\beta$-PNPX & 0 & 0 & 0 \\
$\beta$-PNPG & 0 & 0 & 0 \\
$\beta$-PNPC & 0 & 0 & 0 \\
$\alpha$-PNPA & 0 & 0 & 0 \\
\hline
\end{tabular}

${ }^{a}$ See Table 3.

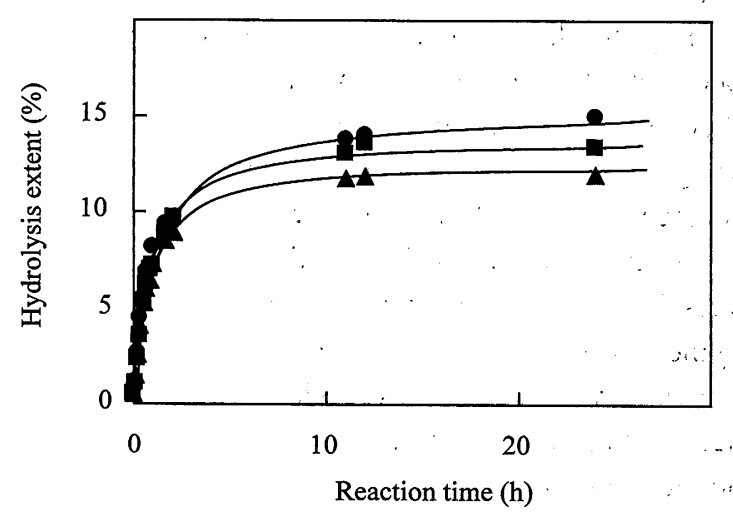

Fig. 5. Hydrolysis extents toward soluble xylan by the purified enzymes.

$\boldsymbol{\bullet}$, xylanase I; $\mathbf{\square}$, xylanase II; $\boldsymbol{\Delta}$, xylanase III.
HPLC. Table 3 shows the degree of hydrolysis and product distribution due to the action of xylanases I, II and III at the late stage of incubation (120 min). The purified enzymes hydrolyzed $X_{5}$ and $X_{6}$ to give $X_{3}$ and $X_{2}$ as the major end products. The enzyme also split $X_{4}$ to give $X_{2}$ as the major end product, however, $\mathrm{X}_{4}$ was considerably harder to be hydrolyzed compared to $\mathrm{X}_{6}$ and $\mathrm{X}_{5}$. The enzymes did not act entirely on either $\mathrm{X}_{3}$ 'or $\mathrm{X}_{2}$ as mentioned above.

\section{Kinetic parameters of the purified enzymes.}

The kinetic parameters for xylooligosaccharides (DP $=4-6)$ were determined by Lineweaver-Burk plots. The $K_{\mathrm{m}}, V_{\max }, k_{0}$ and $k_{0} / K_{\mathrm{m}}$ values of the

Table 3. Degree of hydrolysis and product distribution due to the action of xylanases I, II and III.

\begin{tabular}{|c|c|c|c|c|c|c|c|c|}
\hline \multirow{2}{*}{ Enzyme } & \multirow{2}{*}{$\begin{array}{l}\text { Substrate } \\
(4 \mathrm{mM})\end{array}$} & \multirow{2}{*}{$\begin{array}{c}\text { Degree of hydrolysis } a \\
(\%)\end{array}$} & \multicolumn{6}{|c|}{ Product distribution (mM) } \\
\hline & & & $\mathrm{X}_{6}$ & $\mathrm{X}_{5}$ & $\mathrm{X}_{4}$ & $\mathrm{X}_{3}$ & $\mathrm{X}_{2}$ & $\mathrm{X}_{1}$ \\
\hline \multirow{3}{*}{ Xylanase I } & $\mathrm{X}_{6}$ & 100 & 0 & 0 & 0.56 & 3.96 & 4.02 & 0.42 \\
\hline & $\mathrm{X}_{5}$ & 100 & - & 0 & 0.32 & 3.11 & 3.16 & 0.32 \\
\hline & $\mathrm{X}_{4}$ & 85.6 & - & - & 0.72 & 1.08 & 4.09 & 0.70 \\
\hline \multirow{3}{*}{ Xylanase II } & $\mathrm{X}_{6}$ & 99.4 & 0.03 & 0 & 1.61 & 3.58 & 2.89 & 0.44 \\
\hline & $\mathrm{X}_{5}$ & 97.2 & - & 0.14 & 0.64 & 2.98 & 2.73 & 0.12 \\
\hline & $X_{4}$ & 35.6 & - & - & 3.22 & 0.58 & 1.29 & 0.17 \\
\hline \multirow{3}{*}{ Xylanase III } & $\mathrm{X}_{6}$ & 99.4 & 0.03 & 0 & 1.75 & 3.46 & 2.79 & 0.51 \\
\hline & $\mathrm{X}_{5}$ & 97.8 & - & 0.11 & 0.61 & 2.94 & 2.80 & 0.30 \\
\hline & $X_{4}$ & 42.6 & - & - & 2.87 & 0.66 & 1.59 & 0.37 \\
\hline
\end{tabular}

${ }^{a}$ Calculated from the amount of residual substrate. 
Table 4. Kinetic parameters of xylanases I, II and III for xylooligosaccharides.

\begin{tabular}{|c|c|c|c|c|c|}
\hline & DP & $K_{\mathrm{m}}{ }^{a}$ & $V_{\max } b$ & $k_{0} c$ & $k_{0} / K_{\mathrm{m}}{ }^{d}$ \\
\hline \multirow{3}{*}{ Xylanase I } & 4 & 6.10 & 108 & 26 & 4.3 \\
\hline & 5 & 1.43 & 317 & 151 & 105.6 \\
\hline & 6 & 1.35 & 444 & 212 & 157.0 \\
\hline \multirow{3}{*}{ Xylanase II } & 4 & N.D. ${ }^{e}$ & N.D. ${ }^{e}$ & N.D..$^{e}$ & N.D. ${ }^{e}$ \\
\hline & 5 & 1.64 & 269 & 207 & 126.2 \\
\hline & 6 & 1.00 & 319 & 245 & 245.0 \\
\hline \multirow{3}{*}{ Xylanase III } & 4 & 4.74 & 95 & 36 & 7.6 \\
\hline & 5 & 1.58 & 569 & 212 & 134.2 \\
\hline & 6 & 1.25 & 670 & 250 & 200.0 \\
\hline
\end{tabular}

${ }^{a} \mathrm{mM},{ }^{b} \mu \mathrm{mol} / \mathrm{mg}$ protein $/ \mathrm{min},{ }^{c} \mathrm{~s}^{-1},{ }^{d} \mathrm{mM}^{-1} \mathrm{~s}^{-1},{ }^{e}$ not determined.

purified enzymes are listed in Table 4. The $K_{\mathrm{m}}$ (Michaelis constant) values of the purified enzymes on xylooligosaccharides increased with the increase in DP number of substrates. However the $k_{0}$ (molecular activity) values became almost constant for DP more than 5 .

\section{DISCUSSION}

Three highly purified xylanase components were separated from a commercial cellulase preparation of $A$. cellulolyticus by consecutive column chromatographies of QAE-Toyopearl 550C, DEAEToyopearl 650S, Mono S and Superdex 75. Three purified xylanases showed a single protein band on both Native- and SDS-PAGE, indicating these xylanases are all highly homogeneous. They were designated as xylanase I, xylanase II and xylanase III, respectively.

As shown in Table 1, the specific activity of xylanases I, II and III increased about 59-, 45- and 39-fold, respectively, compared with that in the original crude enzyme extract. The molecular weight $(25.5-33.5 \mathrm{kDa})$ and $\mathrm{p} I(5.1-5.7)$ values of these purified xylanases fairly resemble the reported data from different fungal origins. ${ }^{1,2)}$ As mentioned in Results, the present three xylanases had identical N-terminal amino acid sequences from the 1 st up to the 25 th residue. However, analysis of amino acid sequences by BLASTP (a homology search system for amino acid sequences in protein databases) showed that these enzymes have completely no homology with the known xy- lanases listed or the xylanase from an alkalitolelant filamentous fungus, Acremonium sp. TM28. ${ }^{15)}$

In general, fungal and bacterial xylanases have been roughly grouped into two classes based on their molecular weights. ${ }^{16)}$ Enzymes with molecular weights below $30 \mathrm{kDa}$ are typically basic proteins, whereas those with molecular weights above $30 \mathrm{kDa}$ are usually acidic. Although this trend is not universal, it is particularly apparent among the enzymes from bacteria and the various species of Trichoderma. In our case, xylanases I and III were acidic proteins, however xylanase II was also acidic even at a molecular weight below $30 \mathrm{kDa}$.

The three purified xylanases were similar in regard to optimum $\mathrm{pH}$ and $\mathrm{pH}$ stability, but there were clear differences in the optimum reaction temperature and thermal stability $\left(55^{\circ} \mathrm{C}\right.$ and $\leqq 55^{\circ}$ $\mathrm{C}$ for xylanases I and II, and $50^{\circ} \mathrm{C}$ and $\leqq 50^{\circ} \mathrm{C}$ for xylanase III, respectively). The activities of three xylanases were strongly inactivated by $1 \mathrm{mM}$ $\mathrm{KMnO}_{4}$ and partially by $1 \mathrm{mM}$ SDS, PCMB, $\mathrm{Zn}^{2+}$ and $\mathrm{Ag}^{+}$to various inhibition extents. On the other hand, EDTA and NBS showed no effect on the activities of these xylanases. This suggests that metals and sulfhydryl groups are not essential for the xylanolytic actions of the enzymes, as is the case with cellulases III-A, III-B and IV from this fungus. ${ }^{4,5)}$

The degree of endo-lytic action in the hydrolysis of soluble xylan by three purified xylanases from A. cellulolyticus is shown in Fig. 4. Straight lines with almost the same slopes were obtained 
for these enzymes, indicating the purified enzymes are all typical endo-lytic xylanases. The enzymes were also confirmed to be endo-xylanases judging from the product distribution from xylooligosaccharides $\left(\mathrm{X}_{4}-\mathrm{X}_{6}\right)$.

To investigate substrate specificity, saccharification activities of these xylanases were examined as a measure of the xylanolytic capacity using various xylans. The three enzymes were all incapable of attacking Avicel, CMC, $\mathrm{X}_{3}, \mathrm{X}_{2}$ and various arylglycosides. Certain highly purified endo-xylanases have been reported that are capable of hydrolyzing cellulose in addition to xylan. Furthermore, cellulases have also been described that can attack xylan. ${ }^{17)}$ However, our purified xylanases are not capable of hydrolyzing cellulosic materials at all.

In conclusion, these three purified xylanases seem to be isoforms judging from the many characteristic properties such as isoelectric point, molecular weight, N-terminal amino acid sequence, optimum $\mathrm{pH}, \mathrm{pH}$ stability, mode of action, substrate specificity and kinetic parameters of the enzymes.

The authors wish to express their gratitude to Ms. Naomi Sumida of the Pharmaceutical Technology Laboratories of Meiji Seika Kaisha, Ltd. for her help in conducting amino acid sequence analyses.

\section{REFERENCES}

1 ) R.F.H. Dekker: The hemicellulase group of enzymes. in Polysaccharides in Food, J.M.V. Blanshard and J. R. Mitchell, eds., Butterworths, London, pp. 93-108 (1979).

2 ) R.F.H. Dekker and G.N. Richards: Hemicellulases: Their occurrence, purification, properties, and mode of action. Adv. Carbohydr. Chem. Biochem., 32, 277352 (1976).

3 ) R.F.H. Dekker: Biodegradation of the hemicelluloses. in Biosynthesis and Biodegradation of Wood Components, T. Higuchi, ed., Academic press, Orlando, pp. 505-533 (1985).

4 ) S. Kansarn, N. Matsushita, T. Kono and G. Okada: Purification and characterization of an endo-cellulase from Acremonium cellulolyticus. J. Appl. Glycosci., 47, 177-186 (2000).

5 ) S. Kansarn, T. Nihira, E. Hashimoto, M. Suzuki, T. Kono and G. Okada: Purification and properties of two endo-cellulases from Acremonium cellulolyticus. J. Appl. Glycosci., 47, 293-302 (2000).

6 ) K. Nisizawa and K. Wakabayashi: Enzymatic hydrolysis of $\beta$-cellobioside (I). Seikagaku, 24, 36-43 (1952) (in Japanese).

7 ) M. Somogyi: Note on sugar determination. J. Biol. Chem., 195, 19-23 (1952).

8 ) N. Nelson: A photometric adaptation of the Somogyi method for the determination of glucose. J. Biol. Chem., 153, 375-380 (1944).

9 ) O.H. Lowry, N.J. Rosebrough, A.L. Farr and R.J. Randall: Protein measurement with the folin phenol reagent. J. Biol. Chem., 193, 265-275 (1951).

10) L. Ornstein: Disc electrophoresis I. Background and theory. Ann. N.Y. Acad. Sci., 121, 321-349 (1964).

11) B.J. Davis: Disc electrophoresis II. Method and application to human serum proteins. Ann. N.Y. Acad. Sci., 121, 404-427 (1964).

12) U.K. Laemmli: Cleavage of structural proteins during the assembly of the head of bacteriophage T4. Nature, 227, 680-685 (1970).

13) O. Vesterberg: Isoelectric focusing of proteins in thin layers of polyacrylamide gel. Sci. Tools, 20, 22-29 (1973).

14) H. Lineweaver and D. Burk: The determination of enzyme dissociation constants. J. Am. Chem. Soc., 56, 658-666 (1934).

15) T. Ardyati, Y. Moriyama, T. Hirose, T. Esaki, M. Veerothai, J. Sumitani, T. Kawaguchi and M. Arai: Purification and some properties of xylanase from an alkali-tolerant filamentous fungus, Acremonium sp. TM-28. in Genetics, Biochemistry and Ecology of Cellulose Degradation, K. Ohmiya, K. Hayashi, K. Sakka, Y. Kobayashi and S. Karita, eds., Uni Publishers Co., Ltd., Tokyo, pp. 127-133 (1999).

16) K.K.Y. Wong, L.V.L. Tan and J.N. Saddler: Multiplicity of $\beta-1,4-x y l a n a s e$ in microorganisms: Functions and applications. Microbiol. Rev., 52, 305-317 (1988).

17) S. Shikata and K. Nisizawa: Purification and properties of an exo-cellulase component of novel type from Trichoderma viride. J. Biochem., 78, 499-512 (1975)

(Received August 17, 2000; Accepted September 11, 2000) 
系状菌 Acremonium cellulolyticus 起源の

3 種エンドキシラナーゼの精製と基本性質

仁平高則 ${ }^{1}$, キャンサーンスパンニー1, 河野敏明 ${ }^{2}$, 岡田嚴太郎 ${ }^{1,3}$

1 静岡大学大学院電子科学研究科 (432-8561 浜松市城北 3-5-1)

2 明治製菓株式会社生物科学研究所 (350-0289 坂戸市千代田 5-3-1)

3 静岡大学教育学部(422-8529 静岡市大谷 836 )

系状菌 Acremonium cellulolyticus 起源の市販酵素製剂 から, 各種カラムクロマトグラフィーを組み合わせ, 電気泳動的に均一な 3 種のエンドキシラナーゼを高純 度に精製し，キシラナーゼ I，II，正と呼称した。精 製酵素の分子量および等電点は，それぞれ $30 \mathrm{kDa}$, $5.1 ， 25.5 \mathrm{kDa}, 5.2$, および $33.5 \mathrm{kDa}, 5.7$ であった. $\mathrm{N}$ 末端側第1一第25アミノ酸残基の配列は，3酵素とも $\mathrm{NH}_{2}$-Ala-Glu-Ala-Ile-Asn-Tyr-Asn-Gln-Asn-Tyr-Ile-Ala-Ser-
Gly-Ala-Asn-Val-Gln-Tyr-Ser-Pro-Asn-Ile-Ala-Ala-であっ た。キシラナーゼ I ， II， IIIは，可溶性キシランに高 い反応性を示し，比活性值はそれぞれ 112.1，86.1， $74.8 \mathrm{U} / \mathrm{mg}$ であり, 反応至適 $\mathrm{pH}$ および至適温度は, それぞれ $3.5,55^{\circ} \mathrm{C}, 3.8,55^{\circ} \mathrm{C}$ および $3.5,50^{\circ} \mathrm{C} て ゙$ あった.キシラナーゼ I， II， III は $\mathrm{pH} 3.5-9.5\left(25^{\circ} \mathrm{C}\right.$, 2 時間処理), $55^{\circ} \mathrm{C}$ 以下, $\mathrm{pH} 3.0-9.5,55^{\circ} \mathrm{C}$ 以下および $\mathrm{pH} 2.5-9.5 ， 50^{\circ} \mathrm{C}$ 以下において，それぞれ完全に安定 であった. 3 酵素とも $1 \mathrm{mM}$ の $\mathrm{KMnO}_{4}$ によりほほ完全 に阻害され, $1 \mathrm{mM}$ の SDS, PCMB, $\mathrm{Zn}^{2+}, \mathrm{Ag}^{+}$により 部分阻害を受けた。当該酵素の基質特異性や反応速度 パラメータなどが精査された。キシランおよびキシロ オリゴ糖に対する作用パターンから, 当該 3 酵素はい ずれもエンドキシラナーゼであった． 3 種の精製酵素 は, $\mathrm{N}$ 末端アミノ酸配列, 物理化学的・酵素学的性質, 基質特異性などから，互いにアイソフォームであると 推定された. 